DOI :

\title{
CONSTRUCTION PROJECT PRODUCTIVITY IN INDONESIA
}

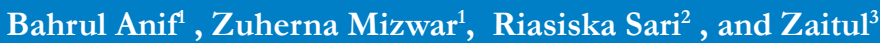

${ }^{1}$ Faculty of Planning and Civil Engineering, Bung Hatta University, Padang, Indonesia

${ }^{2}$ Master Student in Faculty of Planning and Civil Engineering, Bung Hatta University, Padang, Indonesia

${ }^{3}$ Faculty of Economics and Business, Bung Hatta University, Padang, Indonesia

Corresponding Author Email: zaitul@bunghatta.ac.id

\section{Abstract}

The construction industry is a large and important business, which involves millions of workers, such as skilled craftsmen, supervisors, technicians, etc. The selection of a competent workforce affects the productivity of construction project implementation. Furthermore, this productivity affects the quality of the result produced and company profits. Therefore, it is important to understand the factors affecting the productivity of construction project implementation to minimize the problems encountered. This study aims to identify, analyze and determine the dominant factors affecting the productivity of construction project implementation in Indonesia. This was carried out using frequency distribution and multiple linear regression method. The initial identification of factors and variables affecting the construction project implementation's productivity were summarized from previous studies. The number of study samples was 237 respondents with a feasible questionnaire response rate processed at $94.8 \%$. This study uses primary data collected through the survey. Confirmatory factor analysis (CFA) is employed to achieve the research objective. Kaiser-Mayer-Olsen (sample adequacy), Loading factor (validity), Cronbach alpha (Reliability), extracted variation, and percentage of variance are used to confirm the factors suggested by works of literature. The result shows that there are eight factors confirmed in this study: human $\left(X_{1}\right)$, management $\left(X_{2}\right)$, technical $\left(X_{3}\right)$, time $\left(X_{4}\right)$, materials and equipment $\left(X_{5}\right)$, supervision $\left(X_{6}\right)$, motivation $\left(X_{7}\right)$ and work safety (X8). There are, furthermore, three dominant factors based on frequency distribution: human, motivational, and technical factors.
\end{abstract}

Keywords: Construction Project, Productivity, Indonesia

\section{Introduction}

The construction industry covers a wide and varied scope, ranging from housing, roads, bridges, dams, irrigation buildings, schools to hospitals. This industry has affected other sectors, such as iron, concrete, furniture, and wood. It has also involved the development of logistics, heavy equipment, manufacturing, and other industries. The rapid development in the sector has increased competition among other construction companies. In every competition, work quality is one of the most important factors that guarantee to win. Resources are one of the key factors in ensuring a business's success, either service, manufacturing, or construction. Selecting the right resource affects the productivity of construction implementation, which affects the quality of the result produced and company profits. Construction projects are not always implemented smoothly, and sometimes they experience certain limitations which may be in the form of materials, workforce, equipment and many more. When these limitations are not properly handled, it affects the quality, quantity, length of work and ultimately affects the cost.

Furthermore, during the implementation of construction projects in Sungai Penuh City, especially in the Human Settlements Sector at the Department of Public Works and Spatial Planning, certain limitations were experienced, which includes delay in the completion of construction projects, mismatches between the specifications used and those in the contract documents and contrast between work results and the contract documents.

Based on data from the implementation mentioned above, the projects undertaken in the year 2017- 2019 included the construction of office buildings, moderate/heavy rehabilitation, and waste management. About $60.2 \%$ of these projects experienced delays in completion, and several construction projects were not in accordance with the contract documents. Therefore, the construction project's implementation was not achieved under the planned cost, quality, and time. It has a significant impact on the relevant agencies, supervisory consultants and implementing contractors. Therefore, it is important for management to understand the factors affecting the productivity of construction project implementation to minimize these problems. Previous studies have been carried out on the factors affecting work productivity both in the construction and other fields (e.g., Ghoddousi and Hosseini, 2012; Choudhry, 2015; and Tam, Huong, and Ngoc, 2018). Ghoddousi and Hosseini (2012) investigate the sub-contractor productivity in Iran and conclude that nine factors affect productivity: material/tools, construction technology and methods, planning, supervision system, rework, weather, and Jobsite condition. Besides, Choudhry (2015) analyzed the construction productivity concerning safety and documented 
that it is possible to improve productivity and safety on construction projects simultaneously.

Further, Tam, Huong, and Ngoc (2018) study labour productivity in the construction industry. Research on productivity in the construction industry also has been done using Indonesia's data (see, for example, Hernandi and Tamtama, 2020). Most of the studies emphasized on construction project belong to private sectors. There is limited research employing the state own construction project. Therefore, this study aims to investigate the construction productivity in state government own project. Based on the research gap, this study enriches the literature on construction project productivity. This study also contributes to the practical side because productivity in a state-owned construction project could improve by implementing these findings. The rest of this paper consists of a literature review, research methods, result and discussion, and a conclusion.

\section{LITERATURE REVIEW}

\section{Productivity}

Productivity is the ratio between the results achieved (output) divided by the resources used (input). The labour can complete a specified work quantity and determine the success of project implementation. This has two dimensions, which are effectiveness and efficiency (Nizar, 2016). All factors affecting productivity are viewed as a subsystem to show productivity potential, and its reserves are stored. According to Sinungan (2000), the factors affecting the productivity of a construction project are: (i) The quality of workforce used (ii) The level of workforce expertise (skills) (iii) Cultural and educational background (iv) Ability of the workforce to analyze the situation ongoing within the scope of their work and the moral attitude taken (v) the high interest of the workforce in the type of work they are engaged in (vi) the structure of the work, skills and age of the workforce. These factors are further divided into two major parts, which includes (i) internal factors within the workforce, such as morale and behaviour, attendance and tardiness, expertise, teamwork and motivation (ii) external factors, such as environmental conditions, materials, equipment, information, schedule, leadership, control and supervision.

\section{Previous Related Studies}

Previous studies have been carried out on the factors affecting the productivity of construction project implementation in Indonesia and other countries. In Indonesia, the studies were carried out by Tanto (2012) in Malang, Nizar (2016) in Pasuruan and Hernandi et al. (2020) in Jakarta. Meanwhile, the studies abroad were carried out by Aboazoum (2012) in Libya, Chan (2012) in England, Mahamid (2013) in Saudi Arabia, Robbles et al. (2014) in Spain and Mangistu et al. (2016) in Ethiopia. The scope of these studies varied greatly from general to particular jobs. The industries of study focus ranged from manufacturing to the construction industry. Tanto (2012) focused on light steel roofing work, Hernandi (2020) on multistorey building construction projects, Nizar (2016) focused on blacksmiths. Meanwhile, Tam (2018), Chan (2012) and Robles (2014) focused on the construction workers in general, and Mengistu et al. (2016) focused on road construction project workers. The study results of Hernandi et al. (2020) showed ten variables affecting the productivity of construction projects, which includes (i) Changes in work drawings (ii) Limited work area (iii) weather change (iv) Lack of places to rest (v) unavailability of materials (vi) working at heights (vii) construction methods (viii) damaged equipment (ix) misunderstanding between workers ( $\mathrm{x}$ ) delays in inspections. Meanwhile, the study results of Tam et al. (2018) showed that out of the 45 variables affecting the productivity of work implementation, ten greatly affected productivity, which includes (i) workforce experience (ii) workforce discipline (iii) Type of wage payment (iv) Material quality (v) Ability to organize production, (vi) Quality of work equipment (vii) Supervision (viii) Safety equipment (ix) Physical ability (x) Workplace height.

\section{RESEARCH METHOD}

This study uses a quantitative approach. The stakeholders involved in the construction project became the research object. There are four categories of them: owners, contractors, planning consultant, and supervisory consultant. The number of populations based on the projects conducted the last two years in Sungai Penuh city, Indonesia. All people are used as a sample of this research. Primary data collected through the survey was utilized in this study. According to Ferdinand (2002), the number of pieces for factor analysis was at least five times the number of variables which indicated that 235 respondents were the minimum sample size used in this study.

This study was carried out by distributing questionnaires to the Department of Public Works and Spatial Planning, contractors, and supervisory consultants, as parties involved in construction projects. A total of 250 questionnaires were distributed, and 237 were feasible to be processed in the next stage. The response rate was $94.8 \%$, out of which $83.5 \%$ were male, and $16.5 \%$ were female. In terms of age, most respondents were between 31-41 years which accounted for $41.8 \%$ of the total respondent. Meanwhile, in terms of construction experience, $38 \%$ had $6-10$ years of experience, $27.4 \%$ had $1-5$ years, and the remaining $34.6 \%$ had more than ten years of experience. This showed that $72.6 \%$ of respondents have more than five years of experience; therefore, having sufficient knowledge about the construction sector. As many as $65.1 \%$ of respondents have attended training while the other $35.9 \%$ never participated. Besides, as many as $56.1 \%$ had a competency certificate, they have proper competence in their work field. Meanwhile, the remaining 43.9\% of other respondents never had a competency certificate. 
This study utilized the primary data gathered in the survey. Furthermore, the initial identification of study factors and variables were obtained from the results of previous studies. Based on these results, eight factors were identified with 47 variables. Mahamid et al. (2013), Robles et al. (2014), Hickson and Ellis (2014), Thahir et al. (2015), Mengistu et al. (2016), Send and Verma (2018), Tam et al. (2018) and Hernandi and Tamtana (2020) provided the reference sources used. These variables are measured by five scales Likert, ranging from strongly disagree (1) to strongly agree (5). Confirmatory factor analysis is used to analyses the data. The procedure is started with examining Kaiser-Mayer Olsen (Kaiser, 1970), Bartlett test at the first step. It is followed by validity and reliability tests (Nunally, 1978) are conducted by producing the loading factor and using Cronbach alpha for the reliability test. Besides, this study also employed an extracted variance and percentage variance to ascertain no extraction anymore. Factor ranking based on the means of each factor.

\section{RESULT AND DISCUSSION}

Analysis of Result
The literature review results identified eight factors and 47 variables affecting the productivity of construction project implementation in Sungai Penuh City. Testing the questionnaire's validity and reliability, which was declared valid and reliable, were the factors and variables identified. The result of confirmatory factor analysis (CFA) is shown in Table 1 to 8 . The statistic property being used is KMO, extraction variance, percentage of variance, loading factor, Cronbach alpha, and means value.

Table 1 shows the confirmatory factor analysis of the human factor. KMO is greater than 0.5. The results showed that the human factor has the highest average level of influence on the construction project's productivity. This means that based on the influence level, the human factor has a particularly important role in implementing construction projects productivity in Sungai Penuh city.

The second factor is the technical factor. With the value of KMO (0.76), extracted variance (2.8)), percentage of variance $(64.61 \%)$, Cronbach alpha $(0.82)$, and loading factor $(>0.50)$, the assessment for CFA are achieved. Therefore, we

\begin{tabular}{|c|c|c|c|c|}
\hline Factor & item & Statement & Loading Factor & Mean \\
\hline \multicolumn{5}{|c|}{$(\mathrm{KMO}=0.81, \mathrm{EV}=3.27 . \%$ of variance $=40.89 \%$. Cronbach alpha $=0.78$. mean $=4.04)$} \\
\hline \multirow{8}{*}{$\begin{array}{l}\text { Human } \\
\text { Factor }\end{array}$} & hf1 & Worker expertise and experience & 0.679 & 4.21 \\
\hline & hf2 & Worker health condition & 0.717 & 4.18 \\
\hline & hf3 & Worker integrity and loyalty & 0.709 & 4.04 \\
\hline & hf4 & Training and empowerment of workers & 0.667 & 4.12 \\
\hline & hf5 & Worker Commitment to work & 0.649 & 3.91 \\
\hline & hf6 & Worker discipline & 0.616 & 4.10 \\
\hline & hf7 & Number and composition of workers & 0.524 & 4.05 \\
\hline & hf8 & Worker Age & 0.523 & 3.84 \\
\hline
\end{tabular}

Table 1: Factor Structure of Human related factor obtained from the calibration sample using CFA

\begin{tabular}{|c|c|c|c|c|}
\hline Factor & item & Statement & Loading Factor & Mean \\
\hline \multirow{5}{*}{$\begin{array}{l}\text { Motivation } \\
\text { Factor }\end{array}$} & & $(\mathrm{KMO}=0.76, \mathrm{EV}=2.58, \%$ of varia & 82. mean $=4.01$ ) & \\
\hline & mof1 & Late wage payment & 0.816 & 3.96 \\
\hline & mof2 & Low workers' wages & 0.829 & 4.02 \\
\hline & mof3 & Lack of incentives for workers & 0.796 & 4.00 \\
\hline & mof4 & Accident insurance & 0.773 & 4.05 \\
\hline
\end{tabular}

Table 2: Factor Structure of Motivation related factor obtained from the calibration sample using CFA 
can conclude that this factor is confirmed. The highest mean value is accident insurance (4.05). It is followed by low worker's wage (4.02), lack of incentive workers (4.00), and late payment wage payment (3.96).

The fourth factor is the safety factor, with an average influence level of $3.98 \%$. The confirmatory factor analysis assessment indicates that the requirement is achieved $(\mathrm{KMO}=0.69, \mathrm{EV}=2.37$, percentage of variance $=69.20 \%$, Cronbach alpha $=0.77$ ). This factor is explained by four variables related to safety rules, safety equipment, signs, and work accidents. The availability of rules, signs and safety equipment at the project site will guarantee the work accident's possible minimization. Work accidents are related to the availability of work safety equipment and signs at the project site.

The material factor was ranked fifth in affecting the productivity of the construction project implementation in Sungai Penuh city with an influence level of $3.96 \%$. This factor analysis's calibration is accepted due to their statistic property, satisfying the cut off value $(\mathrm{KMO}=0.82, \mathrm{EV}=3.16$, $\%$ of variance $=52.73 \%$, Cronbach alpha $=0.82$ ). The highest means of value is the material quality (4.02). The rest is suitable and efficient equipment (4.01) and lack of equipment during project Implementation (4.01).

The sixth factor affecting the productivity of the construction project implementation in Sungai Penuh city is the management factor with an influence level of $3.93 \%$.

\begin{tabular}{|c|c|c|c|c|}
\hline Factor & item & Statement & Loading Factor & Mean \\
\hline \multirow{8}{*}{$\begin{array}{l}\text { Technical } \\
\text { Factor }\end{array}$} & & $(\mathrm{KMO}=0.75, \mathrm{EV}=3.36 . \%$ of variance $=48.07 \%$. Cronbach alp & mean $=3.99$ ) & \\
\hline & tf1 & Changes to designs and specifications during project implementation & 0.724 & 3.98 \\
\hline & $\mathrm{tf} 2$ & Design clarity and technical specifications & 0.808 & 4.05 \\
\hline & $\mathrm{tf} 3$ & Conformity and consistency between contract documents & 0.640 & 3.95 \\
\hline & $\mathrm{tf} 4$ & Method of executing construction & 0.655 & 4.10 \\
\hline & tf5 & weather changes & 0.583 & 3.88 \\
\hline & tf6 & Limited work area & 0.671 & 3.88 \\
\hline & $\mathrm{tf7}$ & Work complexity & 0.747 & 4.09 \\
\hline
\end{tabular}

Table 3: Factor Structure of Technical related factor obtained from the calibration sample using CFA

\begin{tabular}{|c|c|c|c|c|}
\hline Factor & item & Statement & Loading Factor & Mean \\
\hline \multirow{4}{*}{$\begin{array}{l}\text { Safety } \\
\text { Factor }\end{array}$} & sf1 & Incomplete rules available & 0.861 & 4.00 \\
\hline & sf2 & Availability of Safety equipment & 0.78 & 3.84 \\
\hline & sf3 & Availability of safety signs & 0.68 & 3.95 \\
\hline & $\mathrm{sf} 4$ & Work accident & 0.745 & 4.12 \\
\hline
\end{tabular}

Table 4: Factor Structure of Safety-related factor obtained from the calibration sample using CFA 


\begin{tabular}{|c|c|c|c|c|}
\hline Factor & item & Statement & Loading Factor & Mean \\
\hline \multirow{7}{*}{$\begin{array}{c}\text { Material and } \\
\text { Equipment } \\
\text { Factor }\end{array}$} & \multicolumn{3}{|c|}{$(\mathrm{KMO}=0.82, \mathrm{EV}=3.16 . \%$ of variance $=52.73 \%$. Cronbach alpha $=0.82$. mean $=3.96)$} & \\
\hline & mef1 & Equipment condition and quality & 0.749 & 3.93 \\
\hline & mef2 & Suitable and efficient equipment & 0.819 & 4.01 \\
\hline & mef3 & Lack of equipment during project implementation & 0.721 & 4.01 \\
\hline & mef4 & Quality of material & 0.763 & 4.02 \\
\hline & mef5 & The material storage location is not suitable & 0.64 & 3.81 \\
\hline & mef6 & Shortage or delay in material supply & 0.648 & 3.98 \\
\hline
\end{tabular}

Table 5: Factor Structure of Material \& Equipment related factor obtained from the calibration sample using CFA

\begin{tabular}{|c|c|c|c|c|}
\hline Factor & item & Statement & Loading Factor & Mean \\
\hline \multirow{9}{*}{$\begin{array}{c}\text { Manage- } \\
\text { ment } \\
\text { Factor }\end{array}$} & \multicolumn{4}{|c|}{$(\mathrm{KMO}=9.85, \mathrm{EV}=4.03 . \%$ of variance $=50.31 \%$. Cronbach alpha $=0.86$. mean $=3.93)$} \\
\hline & mf1 & Work planning and scheduling & 0.724 & 3.94 \\
\hline & $\mathrm{mf2}$ & Communication between workers, supervisors and field managers & 0.788 & 3.93 \\
\hline & $\mathrm{mf3}$ & Project implementation according to schedule & 0.784 & 3.93 \\
\hline & $\mathrm{mf} 4$ & Field management & 0.676 & 3.88 \\
\hline & mf5 & Orders change during work & 0.574 & 3.93 \\
\hline & mf6 & The relationship between workers and supervisors & 0.692 & 3.93 \\
\hline & mf7 & Construction manager leadership and competence & 0.758 & 3.92 \\
\hline & $\mathrm{mf} 8$ & An unrealistic schedule & 0.651 & 3.93 \\
\hline
\end{tabular}

Table 6: Factor Structure of Management related factor obtained from the calibration sample using CFA

This factor passed the CFA requirement due to its $\mathrm{KMO}$ and other statistic property $(\mathrm{KMO}=9.85, \mathrm{EV}=4.03, \%$ of variance $=50.31 \%$. Cronbach alpha $=0.86)$. The highest means value is unrealistic schedule (3.93), the relationship between workers and supervisor (3.93), order change during work (3.93), project implementation according to schedule (3.93), and communication (3.93).

The control factor was ranked as the seventh factor affecting the productivity of the construction project work implementation in Sungai Penuh city with an average influence level of $3.91 \%$. the calibration procedure shows that the satisfied value $(\mathrm{KMO}=0.78, \mathrm{EV}=2.59, \%$ of variance $=51.76 \%$, Cronbach alpha $=0.78)$. the important variable is the lack of meetings with workers (3.99). Unclear daily work assignments (3.95), delays in inspection (3.92), and lack workers control (3.92).

The last factor affecting the construction project implementation's productivity is a time factor with an average influence level of $3.77 \%$. the assessment of CFA indicates the satisfied value $(\mathrm{KMO}=0.57, \mathrm{EV}=2.13, \%$ of variance $=42.55 \%$, Cronbach alpha $=0.74)$. the highest means value is Unscheduled worker attendance, go home and rest (3.84).

\section{Discussion}

Regarding the first factor, Tam et al. (2018) also showed that this factor was ranked first in affecting productivity with an average influence level of 4.32. Besides, the study carried out by Hisckson and Ellis (2014) showed that the human factor was ranked first in affecting productivity, with a percentage of $83.3 \%$. However, the study carried out by Enhassi et al. (2007), and Mengistu et al. (2016) provided different results, where the human factor was ranked sixth between the other ten factors studied with influence levels of $76.4 \%$ and $68.16 \%$. Based on these results, the proper management of human resources involved would impact the productivity of construction projects. The results showed that five of the eight variables that explain the human factor were included in the ten most influencing variables on productivity. They have workers' expertise and experience, health conditions, training and empowerment, discipline, number, and composition. This 


\begin{tabular}{|c|c|c|c|c|}
\hline Factor & item & Statement & Loading Factor & Mean \\
\hline \multirow{6}{*}{$\begin{array}{l}\text { Control } \\
\text { Factor }\end{array}$} & & $(\mathrm{KMO}=0.78 ., \mathrm{EV}=2.59 \%$ of & $\mathrm{a}=0.78$. mean $=3 . \subseteq$ & \\
\hline & tif1 & Lack of worker control & 0.734 & 3.92 \\
\hline & tif2 & Delay in inspection & 0.794 & 3.92 \\
\hline & tif3 & Unclear daily work assignments & 0.691 & 3.95 \\
\hline & tif4 & Quality of job records & 0.646 & 3.76 \\
\hline & tif5 & Lack of meetings with workers & 0.725 & 3.99 \\
\hline
\end{tabular}

Table 7: Factor Structure of Control related factor obtained from the calibration sample using CFA

\begin{tabular}{|c|c|c|c|c|}
\hline Factor & item & Statement & Loading Factor & Mean \\
\hline \multirow{6}{*}{$\begin{array}{l}\text { Time } \\
\text { Factor }\end{array}$} & & $(\mathrm{KMO}=0.57, \mathrm{EV}=2.13 . \%$ of variance $=42$ & $=0.74$. mean $=3.77$ ) & \\
\hline & tif1 & The length of working time & 0.51 & 3.84 \\
\hline & tif2 & Unscheduled worker attendance, go home and rest & 0.771 & 3.87 \\
\hline & tif3 & The length of resting time & 0.751 & 3.75 \\
\hline & tif4 & Overtime work & 0.597 & 3.71 \\
\hline & tif5 & Lack of off-day & 0.594 & 3.72 \\
\hline
\end{tabular}

Table 8: Factor Structure of Time related factor obtained from the calibration sample using CFA

shows that these eight variables must be managed properly because they have an important role in increasing productivity in human factors.

The second factor is the motivations. The study results of Tam et al. (2018) also ranked motivation as the second highest factor affecting productivity with an average influence level of 4.03. Meanwhile, Mengistu et al. (2016) carried out the study, and Enhassi et al. (2007) showed different results where motivation was ranked seventh and ninth with influence levels of $68.2 \%$ and $61.85 \%$. Furthermore, this study's motivation factor was explained by four variables with the work accident insurance and low worker wages having the highest influence level of 4.05 and 4.02, respectively. Also, research carried out by Gopal and Murali (2016), Tahir et al. (2015) and Sen et al. (2018) showed that low wages have a high influence level of $85.79 \%, 87 \%$ and $85.79 \%$. This indicated that decent and appropriate wages were very influential for workers; therefore, they affect the productivity of construction projects implementation.

The study carried out by Tahir et al. (2015), and Enhassi (2005) showed that the picture clarity and project specifications provided an influence level of $84 \%$ and $80 \%$. Furthermore, other studies have shown that design changes and complexity have an impact on productivity. Sen et al. (2018) carried out the survey, and Tahir et al. (2015) showed that design changes have an effect of $83.55 \%$ and $69 \%$. In addition, the study carried out by Hickson and Ellis (2015), and Hasson et al. (2018) showed that design complexity has an influence level of $72.50 \%$ and $56.25 \%$. In this study, the construction implementation method was a variable that affected technical factors with the highest average level influence of 4.10. Based on the survey carried out by Hickson and Ellis (2015), Enhassi et al. (2007), Hasson et al. (2018) and Tahir (2015), it was shown that the construction method has a high influence level of $83.33 \%, 62.11 \%, 52.24 \%$ and $62 \%$ on the productivity of construction projects.

According to Ponmalar et al. (2018), Megistu et al. (2016) and Tahir et al. (2015), work accidents have an influence on the productivity of construction project implementation with an influence level of $65 \%, 89.2 \%$ and $77 \%$. Based on the study carried out by Tam et al. (2014), the availability of safety equipment affects productivity by $4.23 \%$. Furthermore, Gopal and Murali (2016) carried out the study, and Tahir et al. (2016) showed that the availability of equipment and safety signs would affect productivity by $83.2 \%$ and $76 \%$. Besides, workers that ignore the established safety rules have an impact on the implementation of construction projects. The study results carried out by Mengistu (2016), and Sen et al. (2018) showed that ignoring safety regulations affect productivity by $86.7 \%$ and $82.96 \%$.

The result from previous studies also shows that material and equipment factors influence the implementation of construction projects. The survey carried out by Tam et al. (2018) ranked material and equipment factors as the thirdhighest factor affecting productivity with an influence level of $3.91 \%$. Meanwhile, Mengistu et al. (2016) carried out the study, and Enhassi et al. (2007) ranked material and equipment factors as the first factor affecting productivity with influence levels of $81.9 \%$ and $77.98 \%$. 
Results from previous studies also show that management factors influence the implementation of construction projects. The study carried out by Tam et al. (2018) showed that management factors provide an influence level of $3.86 \%$ on construction project implementation productivity. Meanwhile, studies carried out by Mahamid et al. (2013), Mengistu et al. (2016) and Hickson and Ellis (2013) showed that management factors affect the productivity of construction project implementation by $66.4 \%, 73.6 \%$ and $76.47 \%$. In terms of variables affecting management factors, Mahamid et al. (2013) showed that poor communication and bad relationships between personnel affected productivity by $76.4 \%$ and 73.\%. Meanwhile, the study carried out by Hassoon et al. (2018) showed that bad planning and fieldwork would affect productivity by $68.7 \%$ and $71.43 \%$.

Mengistu et al. (2016) carried out the study, and Enhassi (2013) showed that the control factor influences the productivity of construction project implementation with influence levels of $68.2 \%$ and $76.12 \%$. Meanwhile, in terms of inspection delays, the study carried out by Tahir et al. (2015), and Enhassi (2017) showed that inspection delays affect productivity by $60 \%$ and $77.63 \%$. In addition, the study carried out by Hickson and Ellis (2013), and Mengistu (2016) showed that the lack of supervision affects productivity as large as $95 \%$ and $84.6 \%$.

Results from previous studies also show that the time factor affects the productivity of construction project implementation. The study carried out by Tam et al. (2018), Mengistu et al. (2016), Enhassi et al. (2007) showed that time factor influences productivity by $3.61,64.7 \%$ and $68.79 \%$. Furthermore, based

on the study carried out by Tahir et al. (2015), Enhassi et al. (2007) and Mengistu (2017) working without holidays has an effect on the productivity of project implementation by $85 \%$, $76.58 \%$ and $61 \%$. Unscheduled workers attendance and the time frame between when they begin, and end work affect productivity by $84.7 \%$. According to Mengistu et al. (2016), the time in which unscheduled workers and attendees start and finish piece affects productivity by $84.7 \%$.

\section{CONCLUSIONS AND SUGGESTIONS}

The following conclusions were drawn (i) The analysis results showed that eight factors and 47 explanatory variables were affecting the productivity of the construction project implementation in Sungai Penuh City. They include human, management, technical, time, material and equipment, control, motivation, and safety, (ii) The analysis results on each affecting factor's influence level showed that all factors were included in the influential category. According to respondents' perceptions, the three factors with the highest average level were human, motivational, and technical factors.
The following suggestions were made based on the study benefits and continuity. (i) The number of factors affecting the productivity of construction project implementation requires that all parties involved prepare for all that is needed to complete the construction project. Therefore, preventing a delay in completing the project work and maximizing the time performance to increase the productivity of construction project implementation in Sungai Penuh City (ii) To increase the productivity of efficient and optimal construction project implementation in Sungai Penuh City, it is necessary to increase the factors affecting productivity, especially control factor which is the most significant in Sungai Penuh City. These control factors include control on workers, work implementation schedules, daily assignments accuracy, clarity of work records and number of meetings with workers. (iii) In implementing construction projects in Sungai Penuh City, good time management is needed because time is one of the most influential factors in increasing productivity. Worker's time management was carried out by arranging the schedule and working hours. The time duration allocated to each worker was regulated by the cooperation agreement and regulations for implementing construction projects in Sungai Penuh City. Furthermore, worker's discipline during working hours needs to be evaluated to reduce ineffectiveness. (iv) In this study, the relationship between each factor was determined using SEM analysis. This was carried out by assessing the level of implementation the field factors have in affecting the productivity of construction workers in Sungai Penuh City.

\section{References}

1. Aboazoum, Hassan M.E., Umar Nimran dan Mochammad Al Mussadieq, 2012, Analysis Factors Affecting Employees Job Performance in Libya, IOSR Journal of Bussiness and Management, Vol. 17, Issue 7, pp. 42-49.

2. Bartlett, M. S (1951). A Further Note on Tests of Significance in Factor Analysis. British Journal of Statistical Psychology, 4 (January), 1-2.

3. Chan, Paul, 2012, Factors Affecting Labour Productivity In The Construction Industry, Association of Researchers in Construction Management, Vol. 2, pp. 791-800.

4. Enshassi, Adnan. 2007, Factors Affecting Labour Productivity In Building Projects In The Gaza Strip, Journal Of Civil Engineering And Management, Vol XIII, No 4, pp. 245-254.

5. Hernandi, Yodie Sekarsari Tamtama, 2020, Faktor-Faktor yang Mempengaruhi Produktivitas Pekerja Pada Pelaksanaan Konstruksi Gedung Bertingkat, JMTS, Jurnal Mitra Teknik Sipil, Vol. 3, No. 2, Mei 2020, Hal 299-312.

6. Hickson, Brent $\mathrm{G}$ dan Leighton A. Ellis, 2014, Factors Affecting Construction Labour Productivity in Trinidad and Tobago, The Journal of the Association of Professional Engineering of Trinidad Tobago, Vol.42. No.1, pp.4-11.

7. Jarkas, A. M., \& Bitar, C. G, 2012, Factor Affecting Construction Labour Productivity in Kuwait. Journal of Construction Engineering Management, 2010, 811-820.http://doi.org/10.1061/(ASCE)CO.1943-7862.0000501.

8. Kaiser H.F. (1970). A second generation little jiffy, Psychometrika, 35(4), 401-415 
9. Mahamid, Ibrahim. 2013, Major Factors Influencing Employee Productivity in The KSA Public Construction Projects, International Journal of Civil \& Environmental Engineering, Vol: 14 No. 01, pp. 16-20.

10. Matondang, DRU, 2017, Analisis Perbandingan Produktivitas Kerja Tukang pada Proyek Konstruksi di Medan dan Pematang Siantar. Tugas Akhir, Universitas Sumatera Utara, Medan.

11. Mengistu, Melese, Prof. Emer T. Quezon dan Getachev Kebede, 2016, Assessment of Factors Affecting Labor Productivity on Road Construction Projects in Oromia Region, Bale Zone. International Journal of Scientific \& Engineering Research, Volume 7, Issue 11, pp. 899-910.

12. Nunnally, J.C. (1978). Psychometric Theory, McGraw-Hill, New York, NY.

13. Rini, IP, 2016, Pengaruh Produktivitas Tenaga Kerja Terhadap Kinerja Waktu Proyek pada Bangunan Bertingkat, J. Infras. 3 (2):127-135.

14. Robles, G., A. Stifi, José L. Ponz-Tienda dan S. Gentes, 2014, Labor Productivity in the Construction Industry: Factors Influencing the Spanish Construction Labor Productivity, International Journal of Civil and Environmental Engineering, Vol:8, No:10, pp. 1061 - 1070.

15. Sen, Er. Shrink dan Er. Sandeep Verma, 2018, Factors affecting labour productivity over the construction sector, International Research Journal of Engineering and Technology (IRJET), Volume: 05 Issue: 05, pp. 3152 -3155 .

16. Sinungan, Muchdarsyah, 2000, Produktivitas Apa dan Bagaimana, Jakarta, Bumi Aksara.
17. Soeharto, Imam, 1989, Manajemen Proyek, Dari Konseptual Sampai Operasional, Jakarta, Erlangga.

18. Tahir, Engr.Muhammad Asadullah, Engr. Hashimhanif, Zuhaib Aslam Shahid Dan Engr Abdullah Hanif, 2015, Factors Affecting Labor Productivity In Building Projects Of Pakistan, Proceedings Of Seventh Theiier International Conference, Singapore, Pp. $38-43$.

19. Tam, Nguyen Van, Nguyen Lien Huong dan Nguyen Bao Ngoc, 2018 Factors Affecting Labour Productivity Of Construction Worker On Construction Site: A Case Of Hanoi, Journal of Science and Technology in Civil Engineering, Vol. 12 No. 5, pp: 127-138.

20. Tanto, Dwi, Sri Murni Dewi dan Sugeng P. Budio, 2012, Faktor-Faktor Yang Mempengaruhi Produktivitas Pekerja Pada Pengerjaan Atap Baja Ringan Di Perumahan Green Hills Malang, Jurnal Rekayasa Sipil, Vol. 6 , No. 1, Hal 69-82.

21. Yuniati, Christiono Utomo, 2012, Analisa Faktor-Faktor yang Mempengaruhi Produktivitas Tenaga Kerja Proyek Konstruksi di Surabaya, Prosiding Seminar Nasional Majamen Teknologo XVI, Program Studi MMT-ITS, Surabaya, 14 Juli 2012.

\section{Citation: Bahrul Anif , Zuherna Mizwar, Riasiska Sari , and Zaitul, "CONSTRUCTION PROJECT PRODUCTIVITY IN} INDONESIA." American Research Journal of Business and Management, Volume 7, Issue No. 1, 2021, pp. 1-9.

Copyright (C) 2021 Bahrul Anif, et al. This is an open access article distributed under the Creative Commons Attribution License, which permits unrestricted use, distribution, and reproduction in any medium, provided the original work is properly cited. 